\title{
Evaluation of a Vertical Axis Wind Turbine for Use in Rural Areas
}

\author{
Rosemar Cristiane Dal Ponte ${ }^{1}$, Enerdan Fernando Dal Ponte ${ }^{1}$, Carlos Eduardo Camargo Nogueira ${ }^{1}$, \\ Jair Antonio Cruz Siqueira ${ }^{1} \&$ Divair Christ $^{1}$ \\ ${ }^{1}$ Universidade Estadual do Oeste do Paraná, Cascavel, Paraná, Brazil \\ Correspondence: Rosemar Cristiane Dal Ponte, Universidade Estadual do Oeste do Paraná, Rua Universitária, \\ 2069, Jardim Universitário, Cascavel, Paraná, CEP: 85.819-110, Brazil. Tel: 55-45-3220-7404. E-mail: \\ rosemardalponte@hotmail.com
}

Received: August 18, 2018

doi:10.5539/jas.v10n12p469

\author{
Accepted: September 23, 2018 \\ Online Published: November 15, 2018 \\ URL: https://doi.org/10.5539/jas.v10n12p469
}

\begin{abstract}
With the constant increase in the need for electricity, the use of wind energy emerges as an alternative that is capable of meeting these demands. Considering that several regions in Brazil have a great potential for wind power, it is necessary to develop technologies and investments to ensure the growth of this energy source. The purpose of this project was to study the technical and economic feasibility of a vertical axis wind turbine, which employed a washing machine motor, a servomotor and an alternator for electricity generation, in order to verify which generation system presents better efficiency. Additionally, the unit costs of the energy produced in each generation system were determined and compared to the value of the electricity tariff charged by the concessionaire for rural consumers. Based on the collected data relating to voltages and electric currents, the power and the wind-mechanical, mechanical-electrical and wind-electrical efficiencies of each generator system were calculated, allowing a comparison between these values. The alternator presented the best wind-mechanical efficiency $(5.02 \%)$ and the best wind-electrical efficiency $(0.47 \%)$. The washing machine motor showed the best mechanical-electrical efficiency (11.33\%). The results showed that the systems have little efficiency in the generation of electricity, and the cost of energy generated indicates values much higher than those practiced by the local electricity concessionaire.
\end{abstract}

Keywords: wind energy, generation systems, efficiency

\section{Introduction}

With increasing demand for electricity and the scarcity of fossil fuel resources, renewable energy sources represent an alternative to meet these demands. Renewable energy sources include biomass, solar power, geothermal power, hydropower, and wind power. As a source of renewable energy, wind energy stands out due its features as a low-cost resource (Pinto, 2014).

Considering that several rural properties in Brazil are located far from the electricity transmission and distribution networks, the development and use of wind turbines appears as a promising route for the generation of electricity, thereby contributing to the social and economic inclusion in rural communities (Simas \& Pacas, 2013).

Wind energy is a way of obtaining renewable, clean source energy that emits no greenhouse gases. It presents advantages such as reduced time of construction of the wind farm, possibility of use of the land for other purposes (agriculture and livestock), ease of expansion, and use in hybrid systems (solar-wind), among others (Gomes \& Henkes, 2015).

According to Aldabó (2002), the energy of the winds that can be transformed into electricity is very low, reaching a maximum of $59.3 \%$ of the total energy (Betz's coefficient).

According to ANEEL (2016), Brazil is privileged in terms of the availability of renewable natural resources for energy use, including water resources, biomass, photovoltaics and wind power, in addition to being one of the countries with a higher percentage of wind power in its energy matrix.

Taking into consideration several regions of the country with great wind potential, the development of technologies and investments is essential to guarantee the growth of this energy source, it being necessary to 
establish means to facilitate the implementation of wind systems in a significant way, to achieve the maximum efficiency of the use and transfer of energy from the wind.

The use of wind energy in the regulatory market began in 2009, through the diversification of the electricity matrix and the priority contracting of renewable sources. Contributing to the insertion of this technology in the Brazilian market, wind farms amounted to $50 \%$ of the contracted electricity generation, with increasingly competitive energy prices, very close to the average values of conventional thermal power plants (Simas \& Pacas, 2013).

The use of vertical axis wind turbines may present advantages, as they have a lower starting speed and can be positioned at lower heights, thereby reducing installation costs and facilitating the maintenance of the electric generator. In addition, they can be safer when used in stronger winds, requiring no additional wind tracking devices, unlike horizontal axis wind turbines (Svendsen \& Merz, 2013).

The main purpose of this work is to evaluate the technical and economic feasibility of deploying a vertical axis wind turbine using different generation systems used in rural areas.

\section{Material and Methods}

The present study was developed in the Metalworking laboratory of SENAI (National Service for Industrial Training), Cascavel unit, state of Paraná (Brazil), with geographic location defined by coordinates $24^{\circ} 58^{\prime} \mathrm{S}$ latitude and $53^{\circ} 26^{\prime} \mathrm{W}$ Longitude and an average altitude of 781 meters above sea level.

A vertical axis wind turbine developed by Dal Ponte (2017) was used to analyze and compare the electricity generation efficiency, with a mass of approximately $20.70 \mathrm{~kg}$, according to Figure 1.

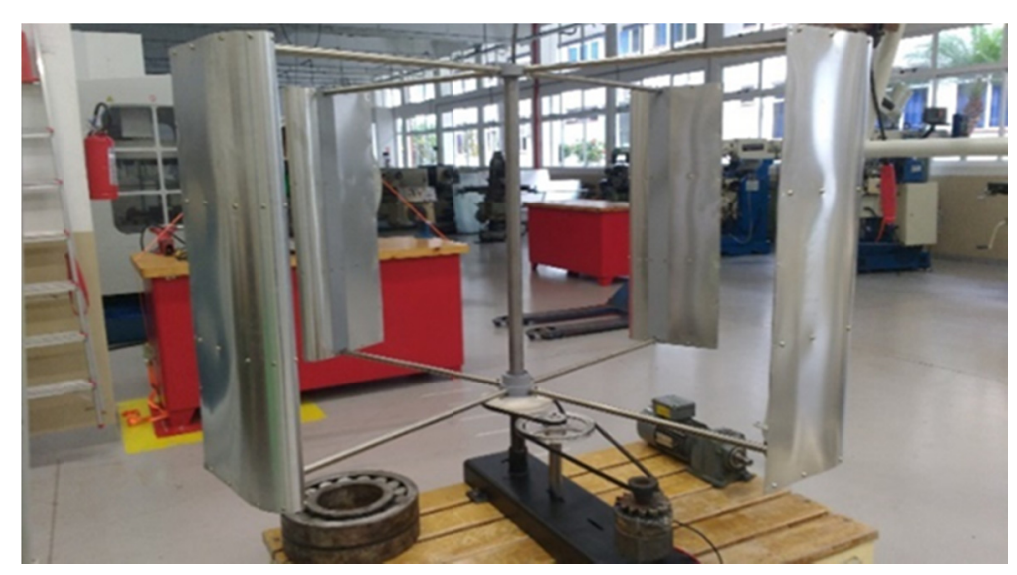

Figure 1. Vertical axis wind turbine

Source: Dal Ponte, 2017.

The vertical axis turbine developed was based on the H-Darrieus model, consisting of blades, frame, bearings and a main shaft, with the following external dimensions: $2000 \mathrm{~mm}$ in diameter per $1000 \mathrm{~mm}$ in height.

Figure 2 shows the coupling of the wind turbine to the washing machine motor, servomotor and automotive alternator, composed of pulleys and belts. This set has a transformation ratio that totals a magnification of 10.8 times. 

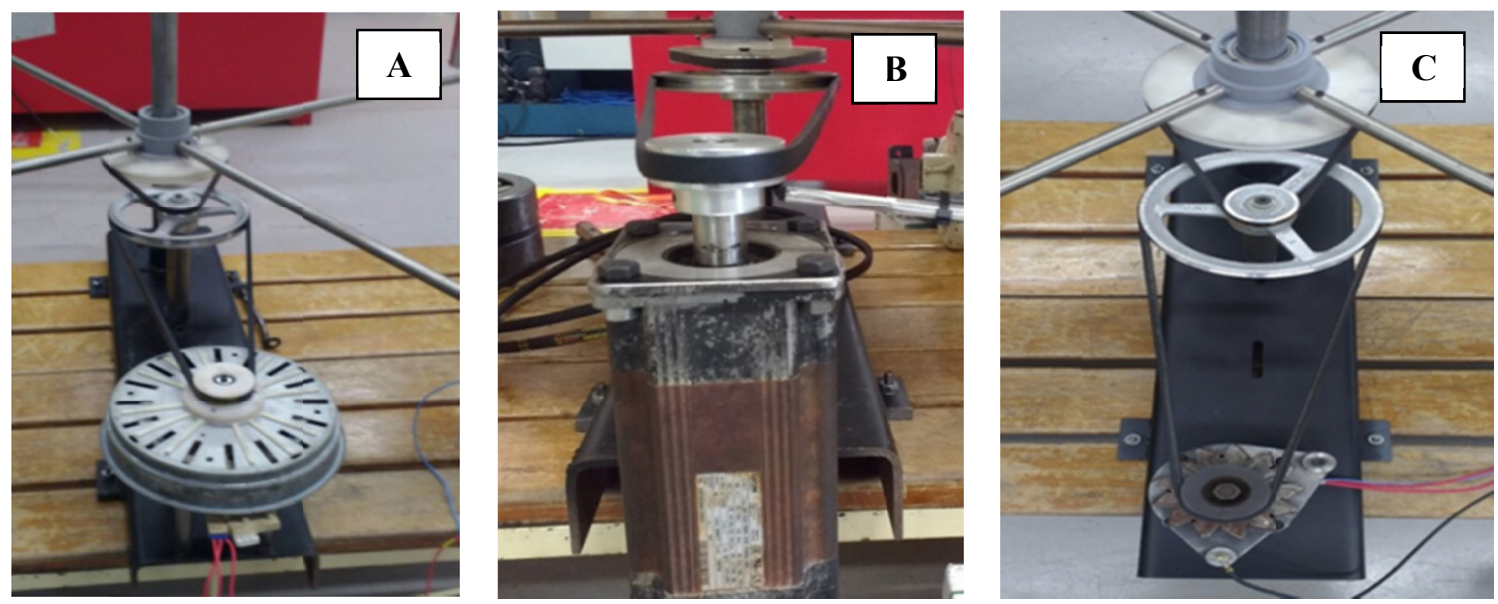

Figure 2. Motor rotation magnification assembly

Note. (A) washing machine motor coupling; (B) servomotor coupling; (C) automotive alternator coupling.

For the proposed development, the motors (operating as generators) were used according to the specifications below:

(a) Washing machine motor (alternating current with permanent magnets and rectifier), Electrolux brand, DON1300WN/ST model - three-phase, with a maximum power of 1,350 watts, maximum voltage of $127 \mathrm{~V}$, and a maximum rotation of $1400 \mathrm{rpm}$;

(b) Servomotor (alternating current), Lenze brand, MCS12L20 model — three-phase, with maximum power of $2.8 \mathrm{~kW}$, maximum voltage of $330 \mathrm{~V}$, and a maximum rotation of $1,950 \mathrm{rpm}$;

(c) Automotive alternator (alternating current), Bosch brand, with power of $540 \mathrm{~W}$, and voltage of $12 \mathrm{~V}$.

The tests were carried out for each generator under study, using an axial fan, with dimensions of $700 \mathrm{~mm}$ in diameter and $400 \mathrm{~mm}$ in depth, with a three-phase motor of $7.5 \mathrm{hp}$ and $220 \mathrm{~V}$, controlled by a frequency inverter of the WEG brand, CFW 08 model, with the aim of increasing wind speed, to put the turbine in motion.

To avoid wind dispersion and try to approach the tests of real field situations by directing the air, a wind tunnel was built and the wind turbine was positioned in its interior.

For each generator, the following data were collected: wind speed using a thermo-anemometer of the Instrutherm TAFR-180 model; generator shaft rotation using a digital tachometer of the Minipa MDT-2244B model; the force exerted by the turbine blades with the aid of a digital dynamometer of the Instrutherm DD-500 model; voltage and alternating current, with the aid of multimeters of the Tenma 72-6870 model and pliers ammeters of the Minipa ET- 3990 model.

In order to verify the behavior of the electricity generation in different load variations, a resistor bank was dimensioned, totaling $25 \mathrm{~W}$ of theoretical maximum load, connected in parallel, ad in order to vary the load, the resistors were fractionated into $10 \mathrm{k} \Omega, 5 \mathrm{k} \Omega, 3.33 \mathrm{k} \Omega, 2.5 \mathrm{k} \Omega, 2 \mathrm{k} \Omega$.

The wind speed, generator shaft rotation, force exerted by the turbine, voltage and alternating current were initially collected for a no-load system. For each step, the stipulated time was 3 minutes. Subsequently, a switch was turned on, triggering a load of $10 \mathrm{k} \Omega$. The same procedure was performed for the loads of $5 \mathrm{k} \Omega, 3.33 \mathrm{k} \Omega$, $2.5 \mathrm{k} \Omega$, and $2 \mathrm{k} \Omega$, a time of 18 minutes being added.

The positioning of the motors and measuring equipment used can be seen in Figures $3 \mathrm{a}$ and $3 \mathrm{~b}$. 


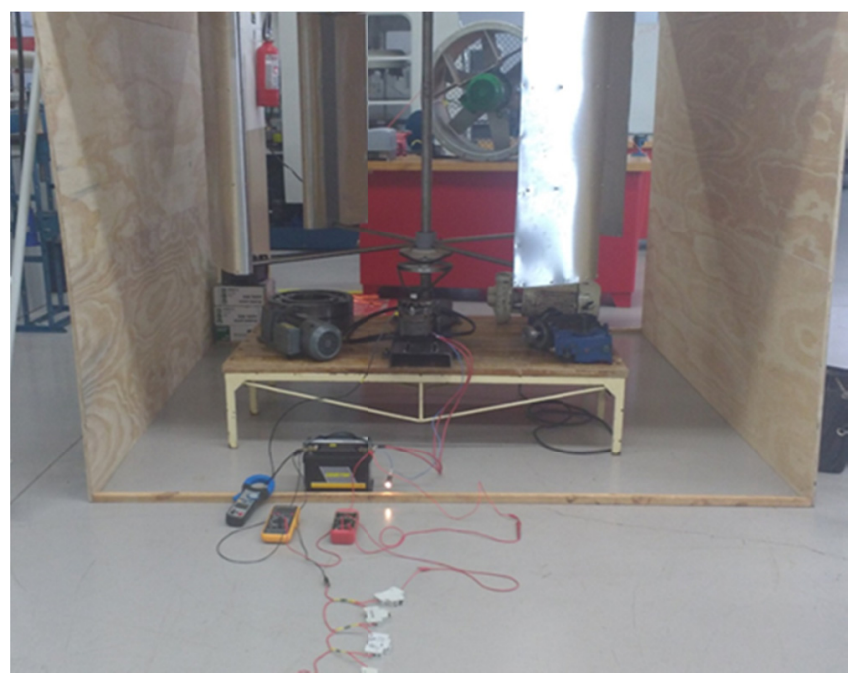

Figure 3a. Positioning of measuring instruments

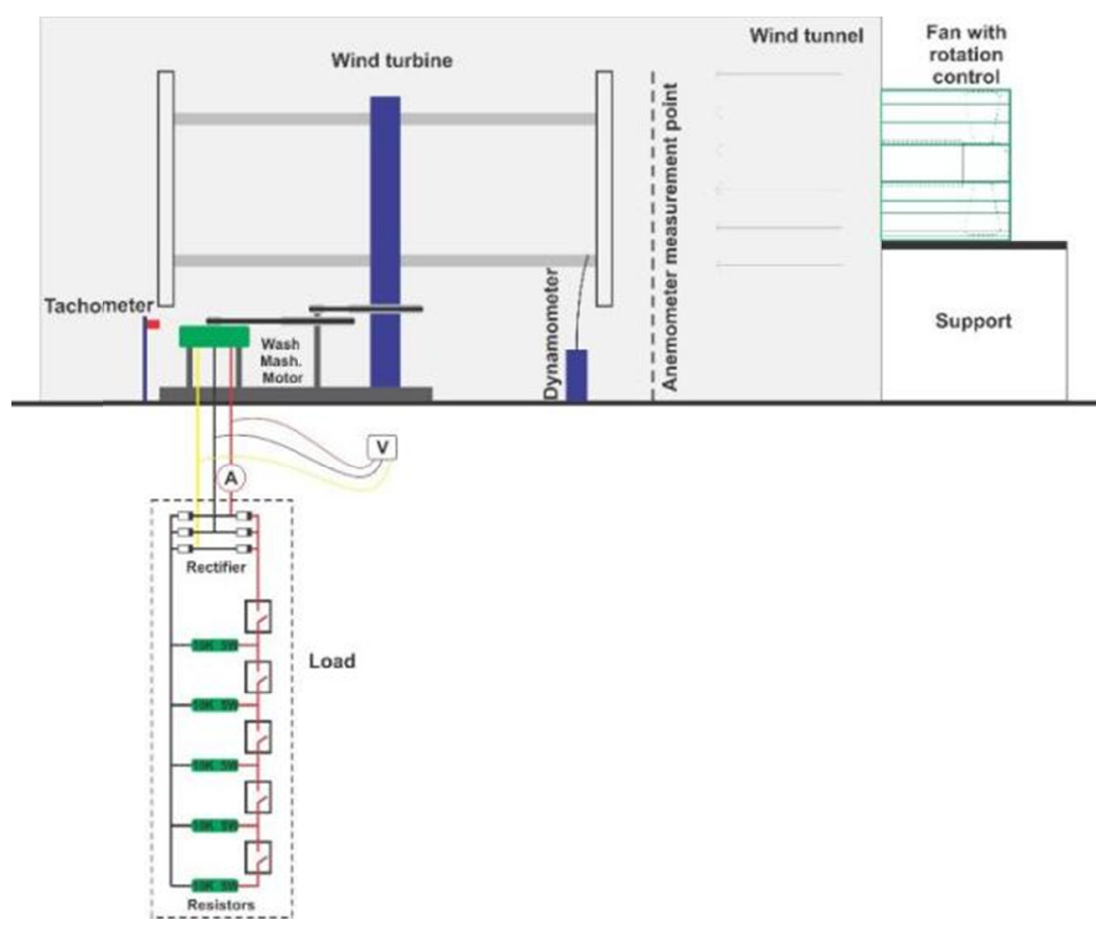

Figure 3b. Generation system assembly

Based on the data collected, the wind power, mechanical power, electrical power and efficiency of each system were calculated, in accordance with the following equations:

$$
\begin{gathered}
\text { Wind Power }(\mathrm{W})=1 / 2 \rho \mathrm{Av}^{3} \rho \\
\text { Mechanical Power }(\mathrm{W})=[\text { Torque }(\mathrm{Nm}) \times \text { Shaft rpm }] / 9.555 \\
\text { Electrical Generation Power }(\mathrm{W})=\operatorname{Voltage}(\mathrm{V}) \times \text { Current }(A)
\end{gathered}
$$

Wind-Mechanical Efficiency $(\%)=[$ Mechanical Power $(W)] /[$ Wind Power $(\mathrm{W})] \times 100 \%$

Mechanical-Electrical Efficiency $(\%)=[$ Mechanical Power $(\mathrm{W})] /[$ Wind Power $(\mathrm{W})] \times 100 \%$

Wind-Electrical Efficiency $(\%)=[$ Electrical Generation Power $(W)] /[$ Wind Power $(W)] \times 100 \%$

$$
\text { Energy }(\mathrm{Wh})=[\text { Power }(\mathrm{W}) \times \text { Measurement time interval }(\mathrm{min})] / 60
$$


Wind power was calculated with a mean wind speed of $12.84 \mathrm{~m} / \mathrm{s}$, turbine area of $2 \mathrm{~m}^{2}$ and air density of 1,225 $\mathrm{kg} / \mathrm{m}^{3}$, according to Equation 1 .

The mechanical power was calculated according to the data collected from the value of the torque $(\mathrm{Nm})$ and the turbine rotation for each generation system, according to Equation 2.

The calculation of the electrical power was based on the data collected from the voltage and the alternating current of the different generation systems, according to Equation 3.

For the purposes of cost comparison, a constant wind speed was considered throughout the year. Similar to the values stipulated in this experiment, with a wind turbine operating availability factor of $90 \%$ of total annual hours, resulting, therefore, in 7884 hours/year of effective power generation. In the remaining 10\% (876 hours/year), it was considered that the wind turbine will be stopped for maintenance.

To calculate the annual energy generation in each system, the average power multiplied by the number of hours was used.

\section{Results and Discussion}

From the three replications for each generation system, each of 18 minutes duration, the average of the wind power generation systems was calculated, and the results are described in Tables 1,2 and 3. In table 1, the data collected referring to the average of the tests performed with the washer motor.

Table 1. Data acquired from the means of the washing machine motor tests

\begin{tabular}{llllll}
\hline Load & Vac (V) & Iac (A) & Generator rotation (rpm) & Turbine rotation (rpm) & Alternating power (W) \\
\hline Open Circuit & 44.00 & 0 & 164 & 15 & 0 \\
$10 \mathrm{k} \Omega$ & 34.00 & 0.049 & 139 & 12 & 2.89 \\
$5 \mathrm{k} \Omega$ & 33.10 & 0.048 & 126 & 1 & 1.75 \\
$3.33 \mathrm{k} \Omega$ & 25.40 & 0.034 & 89 & 8 & 1.50 \\
$2.5 \mathrm{k} \Omega$ & 20.40 & 0.029 & 85 & 7 & 1.02 \\
$2 \mathrm{k} \Omega$ & 22.90 & 0.029 & 80 & 7 & 1.15 \\
\hline
\end{tabular}

The data in Table 1 above show the variations in the added load; the mean of the alternating and average voltages of the alternating currents between the washing machine motor and the bridge rectifier; the mean rotations of the main shaft of the turbine, which was calculated based on the drive shaft rotations and the multiplication factor of the expansion assembly composed of pulleys; and the alternating power obtained by the multiplication between the voltage and the alternating current expressed in $\mathrm{W}$.

According to the table above, it is possible to observe that as the load increases (that is, the resistance decreases), the power values also decrease. This fact occurs due to the technical characteristics of the generator and the load, considering that the motor of the washing machine presents limited generation potential in relation to the required load demand.

In Table 2 it is shows the data referring to the means of the tests performed with the servomotor.

Table 2. Data acquired from the means of the servomotor tests

\begin{tabular}{llllll}
\hline Load & Vac $(\mathrm{V})$ & Iac $(\mathrm{A})$ & Generator rotation $(\mathrm{rpm})$ & Turbine rotation $(\mathrm{rpm})$ & Alternating power $(\mathrm{W})$ \\
\hline Open Circuit & 152.30 & 0 & 641 & 59 & 0 \\
$10 \mathrm{k} \Omega$ & 114.70 & 0.00012 & 537 & 49 & 0.02 \\
$5 \mathrm{k} \Omega$ & 161.20 & 0.00568 & 174 & 16 & 1.59 \\
$3.33 \mathrm{k} \Omega$ & 142.50 & 0.01465 & 165 & 15 & 3.62 \\
$2.5 \mathrm{k} \Omega$ & 158.50 & 0.03029 & 156 & 14 & 8.32 \\
$2 \mathrm{k} \Omega$ & 160.00 & 0.03016 & 151 & 13 & 8.36 \\
\hline
\end{tabular}

According to the data presented in Table 2, as the load increases (i.e., resistance decreases), the power values also increase. This occurs because of the technical characteristics of the generator and the load, considering that 
the servomotor has a higher generation potential than the one required by the load, thereby indicating that more load could be added and, subsequently, a higher generation could be obtained.

In Table 3 it is shown the data referring to the means of the tests performed with the automotive alternator.

Table 3. Data acquired from the means of the automotive alternator tests

\begin{tabular}{llllll}
\hline Load & Idc $(\mathrm{A})$ & Iac $(\mathrm{V})$ & Generator rotation $(\mathrm{rpm})$ & Turbine rotation $(\mathrm{rpm})$ & Generator Power/Battery $(\mathrm{w})$ \\
\hline Open Circuit & 0 & 12.58 & 981 & 90 & 0 \\
$10 \mathrm{k} \Omega$ & 1.20 & 12.68 & 938 & 86 & 15.22 \\
$5 \mathrm{k} \Omega$ & 1.10 & 12.67 & 940 & 87 & 13.94 \\
$3.33 \mathrm{k} \Omega$ & 0.70 & 12.72 & 947 & 87 & 8.90 \\
$2.5 \mathrm{k} \Omega$ & 0.90 & 12.75 & 945 & 87 & 11.48 \\
$2 \mathrm{k} \Omega$ & 0.88 & 12.88 & 949 & 87 & 11.33 \\
\hline
\end{tabular}

As presented in Table 3, as the load increases (i.e., resistance decreases), the power values also decrease. Notwithstanding, when comparing the behavior of the alternator with the washing machine motor, it is observed that both presented limitations in relation to the load. It was verified that the alternator presented greater generation potential.

Table 4 presents the data on the electrical power generated in each system, considering the variation of resistive loads mounted in parallel.

Table 4. Generated electrical power

\begin{tabular}{llll}
\hline Load & Washing Machine Motor Power $(W)$ & Servomotor Power $(W)$ & Battery Power (W)/Alternator Load \\
\hline Open Circuit & 0 & 0 & 0 \\
$10 \mathrm{k} \Omega$ & 2.89 & 0.02 & 15.22 \\
$5 \mathrm{k} \Omega$ & 2.75 & 1.59 & 13.94 \\
$3.33 \mathrm{k} \Omega$ & 1.50 & 3.62 & 8.90 \\
$2.5 \mathrm{k} \Omega$ & 1.02 & 8.32 & 11.48 \\
$2 \mathrm{k} \Omega$ & 1.15 & 8.36 & 11.33 \\
\hline
\end{tabular}

In Figure 4 it is shown the comparison between the mean of the resistive load variations and the mean power (W) generated by the different systems. It is verified that the highest generated powers were obtained by the automotive alternator, using a resistive load of $10 \mathrm{k} \Omega$, which generated $15.22 \mathrm{~W}$. The lowest power generated by the alternator was of $8.90 \mathrm{~W}$ for a load of $3.33 \mathrm{k} \Omega$.

The servomotor presented powers of $1.59 \mathrm{~W}$ and $8.36 \mathrm{~W}$ for loads of $5 \mathrm{k} \Omega$ and $2 \mathrm{k} \Omega$.

The washing machine motor showed the lowest power among the systems analyzed, generating $2.89 \mathrm{~W}$ for a load of $10 \mathrm{k} \Omega$ and $1.02 \mathrm{~W}$ for a load of $2.5 \mathrm{k} \Omega$. 


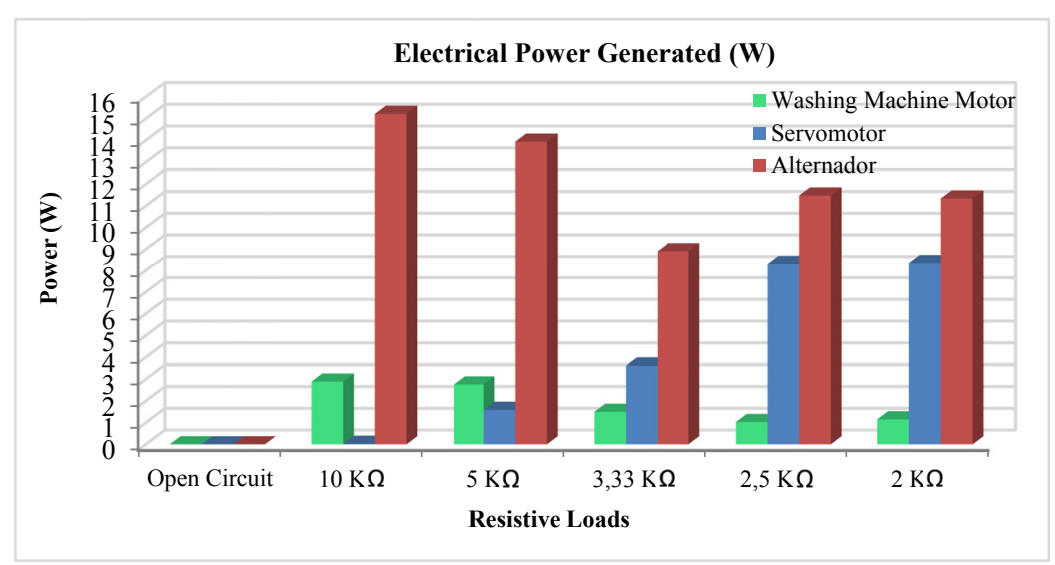

Figure 4. Electrical power generated

In Table 5 it is shown the data on the mechanical power available, generated in each system.

Table 5. Mechanical power available

\begin{tabular}{|c|c|c|c|c|c|c|c|c|c|}
\hline \multirow[b]{2}{*}{ Load } & \multicolumn{3}{|c|}{ Washing Machine Motor } & \multicolumn{3}{|c|}{ Servomotor } & \multicolumn{3}{|c|}{ Alternator } \\
\hline & $\begin{array}{l}\text { Turbine } \\
\text { Rotation } \\
\text { (rpm) }\end{array}$ & $\begin{array}{l}\text { Torque } \\
(\mathrm{Nm})\end{array}$ & $\begin{array}{l}\text { Mechanical } \\
\text { Power (W) }\end{array}$ & $\begin{array}{l}\text { Turbine } \\
\text { Rotation } \\
(\mathrm{rpm})\end{array}$ & $\begin{array}{l}\text { Torque } \\
(\mathrm{Nm})\end{array}$ & $\begin{array}{l}\text { Mechanical } \\
\text { Power (W) }\end{array}$ & $\begin{array}{l}\text { Turbine } \\
\text { Rotation } \\
(\mathrm{rpm})\end{array}$ & $\begin{array}{l}\text { Torque } \\
(\mathrm{Nm})\end{array}$ & $\begin{array}{l}\text { Mechanica } \\
\text { Power (W) }\end{array}$ \\
\hline Open Circuit & 15 & 10.47 & 16.44 & 59 & 18.09 & 111.70 & 90 & 13.81 & 130.08 \\
\hline
\end{tabular}

According to the table above, it is possible to verify the system that presented the highest mechanical power available, i.e., the automotive alternator, which generated $130.08 \mathrm{~W}$. The servomotor system presented a power of $111.70 \mathrm{~W}$, while the washing machine motor had lower power, reaching $16.44 \mathrm{~W}$.

The data on wind-mechanical efficiency obtained in the systems according to the variation of resistive loads mounted in parallel, in relation to a mean wind speed of $12.84 \mathrm{~m} / \mathrm{s}$, generating a wind power of $2593.17 \mathrm{~W}$.

Through Figure 5, it is possible to establish a comparison between wind power and mechanical power, enabling the verification of the system that showed the best wind-mechanical efficiency percentage. The alternator was the most efficient with a percentage of $5.02 \%$. In turn, the servomotor presented an efficiency of $4.31 \%$ and the washing machine motor presented a percentage of $0.63 \%$.

As observed in Figure 5, independent of the loads used, the percentage of wind/mechanical efficiency remained constant.

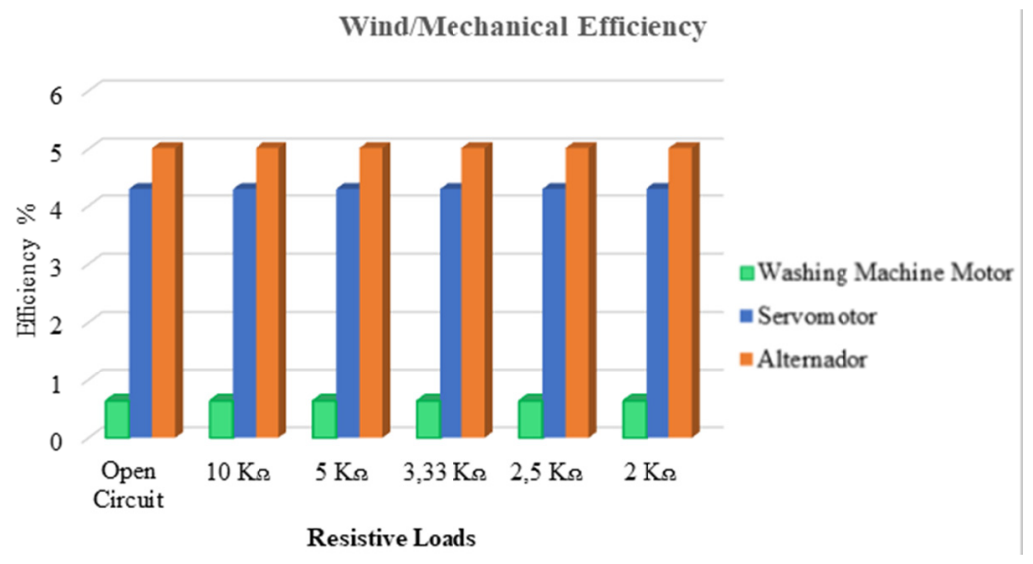

Figure 5. Wind-mechanical efficiency of the systems 
In Figure 6, it is possible to verify which system presented the best mechanical-electrical efficiency percentage. The system that used the washing machine motor was the most of efficient for resistive loads of $10 \mathrm{k} \Omega, 5 \mathrm{k} \Omega$, and $3.33 \mathrm{k} \Omega$, with percentages of $17.56 \%, 16.74 \%$, and $9.10 \%$ respectively.

The servomotor presented efficiencies of $7.48 \%$ and $7.44 \%$ for the loads of $2 \mathrm{k} \Omega$ and $2.5 \mathrm{k} \Omega$. The alternator presented efficiencies of $11.70 \%$ for a resistance of $10 \mathrm{k} \Omega$ and $10.71 \%$ for $5 \mathrm{k} \Omega$.

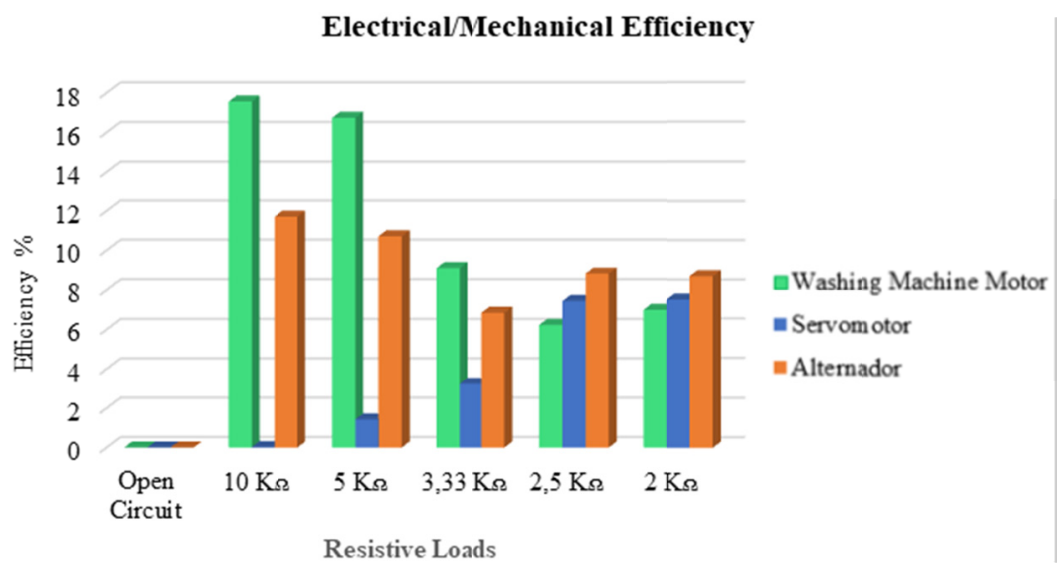

Figure 6. Mechanical-electrical efficiency of the systems

According to Figure 7, the generation system that used the servomotor obtained an efficiency percentage of $0.06 \%$ for a resistive load of $5 \mathrm{k} \Omega$ and $0.32 \%$ for a load of $2 \mathrm{k} \Omega$. The system that used the automotive alternator obtained an efficiency percentage of $0.58 \%$ for a resistive load of $10 \mathrm{k} \Omega$ and $0.34 \%$ for $3.33 \mathrm{k} \Omega$. The system that used the washing machine motor was the least productive, with the lowest efficiency percentage, reaching $0.11 \%$ for $10 \mathrm{k} \Omega$ and $0.04 \%$ for a load of $2.5 \mathrm{k} \Omega$.



Figure 7. Wind-Electrical efficiency of the systems

In Table 6 it is shown the data referring to the mean efficiencies obtained in the different systems.

Table 6. Mean efficiency percentages

\begin{tabular}{llll}
\hline Motor & Wind/Mechanical Efficiency & Mechanical/Electrical Efficiency & Wind/Electrical Efficiency \\
\hline Washing Machine Motor & 0.63 & 11.33 & 0.07 \\
Servomotor & 4.31 & 3.92 & 0.17 \\
Alternator & 5.02 & 9.36 & 0.47 \\
\hline
\end{tabular}


On Table 6, it can be observed that the system that used the automotive alternator was the one that obtained the highest mean wind-mechanical efficiency, reaching 5.02\%, followed by the servomotor with $4.31 \%$ for this efficiency. The washing machine motor had the lowest wind-mechanical efficiency, reaching $0.63 \%$. The system that used the washing machine motor showed the highest mechanical-electrical efficiency, at $11.33 \%$, followed by the system that operated with the alternator, with $9.36 \%$, and the servomotor, with $3.92 \%$. For wind-electrical efficiencies, all systems presented low percentages, ranging from $0.07 \%$ to $0.47 \%$.

In Table 7 it is shows the data referring to initial and maintenance costs for the installation of the different power generation systems.

Table 7. System costs

\begin{tabular}{llll}
\hline & Washing Machine Motor & Servomotor & Alternator \\
\hline Initial cost of the system in R \$ (turbine + motor) & $2,263.07$ & $2,462.57$ & $1,776.07$ \\
Service life (years) & 20 & 20 & 20 \\
Maintenance cost p.a. in R\$ (2\% of the initial cost & 45.26 & 49.25 & 35.22 \\
\hline
\end{tabular}

Considering a 4-year automotive battery life according to the manufacturer's specifications, and considering $10 \%$ p.a. interest rate as benchmark of the financial market; the annual cost of the battery used in the generator system with the alternator was R\$ 141.66 .

Similarly, using an interest rate of $10 \%$ pa and a 20 -year useful life, according to engine manufacturer specifications, the costs per year for the washer motor ( $\mathrm{R} \$ 311.06)$, the servomotor ( $\mathrm{R} \$ 338.48)$ and the automotive alternator $(\mathrm{R} \$ 385.79)$.

Considering that the energy system is expected to operate 7884 hours/year, the calculations of the total energy per generator used are exemplified below:

Total Annual Washing Machine Energy $=1.86 \times 7.884$

Total Annual Washing Machine Energy $=14.6642 \mathrm{kWh} /$ year

Total Annual Servomotor Energy $=4.38 \times 7.884$

Total Annual Servomotor Energy $=34.5319 \mathrm{kWh} /$ year

Total Annual Alternator Energy $=12.17 \times 7.884$

Total Annual Alternator Energy $=95.9483 \mathrm{kWh} /$ year

Table 8 presents data on annual investment costs, annual energy generated (kWh/year), and the cost of energy generated by the systems in $\mathrm{R} \$ \mathrm{kWh}$.

Table 8. Costs vs. energy generated

\begin{tabular}{llll}
\hline System & Costs/Annual Investment (R\$) & Annual energy generated $(\mathrm{kWh})$ & Cost/Energy Generated $(\mathrm{R} \$ / \mathrm{kWh})$ \\
\hline Washing Machine Motor & 311.06 & 14.66 & 21.21 \\
Servomotor & 338.48 & 34.53 & 9.80 \\
Alternator & 385.79 & 95.95 & 4.02 \\
\hline
\end{tabular}

In Table 8, it is possible to establish a comparison between the generated energy (kWh) and the energy cost generated in $(\mathrm{R} \$ / \mathrm{kWh})$ for each system. The automotive alternator generated an annual energy of $95.95 \mathrm{kWh}$, and the cost of energy was $\mathrm{R} \$ 4.02 / \mathrm{kWh}$. This system was the one that presented the best unit cost.

Compared with the data from the auctions held in December 2017, wind energy obtained a mean marketing price of $\mathrm{R} \$ 0.19$ per $\mathrm{kWh}$. The costs of energy generated $(\mathrm{R} \$ / \mathrm{kWh})$ in the analyzed systems were higher than the final values practiced by the market (MME, 2017).

\section{Conclusions}

It was possible to verify in this work, the technical-economical feasibility of the implantation of a vertical axis wind turbine using different systems, for the generation of electric energy. The studied systems presented low 
efficiency indexes, due to the characteristics of the resistive loads used in the generation systems that were adapted, and of the wind turbine efficiency itself.

Through the analysis of the results obtained, it was verified that the automotive alternator was the system that presented the best wind mechanical efficiency $(5.02 \%)$ and the best wind electric efficiency $(0.47 \%)$. The motor of the washing machine, in turn, presented the best mechanical-electrical efficiency $(11.33 \%)$.

The system that used the automotive alternator generated $95.95 \mathrm{kWh}$ per year, costing $\mathrm{R} \$ 4.02 / \mathrm{kWh}$, which presented the best unit cost. Through the economic feasibility analysis, it was verified that the systems presented high energy costs generated, when compared to the electricity tariffs charged by Copel, whose value for the rural subgroup B2 is $\mathrm{R} \$ 0.48 / \mathrm{kWh}$ plus taxes.

\section{References}

Aldabó, R. L. (2002). Energia eólica (1st ed.). São Paulo: Artliber.

ANEEL (Agência Nacional de Energia Elétrica). (2017). Retrieved from http://www.aneel.gov.br

Betz, A. (1920). The Maximum of the theoretically possible exploitation of wind by means of a wind motor. Wind Engineering, 37(4), 441-446. https://doi.org/10.1260/0309-524X.37.4.441

COPEL (Companhia Paranaense de Energia Elétrica). (2018). Retrieved from http://www.copel.com.br

CRESESB (Centro de Referência em Energia Solar e Eólica). (2016). FAQ Eólica (Perguntas frequentes). Retrieved from http://www.cresesb.cepel.br/content.php

Dal Ponte, F. E. (2017). Construção e avaliação de um aerogerador de eixo vertical aplicado à agroindústria (Dissertação Mestrado, Universidade Estadual do Oeste do Paraná, Cascavel, PR).

Dutra, R. M., \& Tolmasquim, M. T. (2002). Estudo da viabilidade econômica para projetos eólicos com base no novo contexto do setor elétrico. Revista Brasileira de Energia, 9(1).

Gomes, L. E. B., \& Henkes, J. A. (2015). Análise da energia eólica no cenário elétrico: Aspectos gerais e indicadores de viabilidade econômica. Gestão e Sustentabilidade Ambiental, 3(2), 463-482.

Hirschfeld, H. (2000). Engenharia econômica e análise de custos: Aplicações práticas para economistas, engenheiros, analistas de investimentos e administradores (7th ed.). São Paulo: Editora Atlas.

Junior, F. G. C. J., \& Rodrigues, G. M. (2015). Um Estudo sobre a Energia Eólica no Brasil. Revista Ciência Atual, 5(1), 02-13.

MME (Ministério de Minas e Energia). (2017). Retrieved from http://www.mme.gov.br/web/guest/pagina-inicial/ outras-noticas/-/asset_publisher/32hLrOzMKwWb/content/leiloes-de-energia-existente-contratam-12-466-g wh-e-movimentam-2-19-bilhoes-de-reais

Pinto, M. O. (2014). Fundamentos de Energia Eólica (1st ed.). Rio de Janeiro: Editora LTC.

Rabe. J. (2016). Energia eólica no mundo cresce de vento em popa. Retrieved from http://www.dw.de/dw/ article/0,,6365833,00.html

Svendsen, H. G., \& Merz, K. O. (2013). Control System for Start-up and Shut-down of a Floating Vertical Axis Wind Turbine. Energy Procedia, 35(41), 33-42. https://doi.org/10.1016/j.egypro.2013.07.156

Simas, M., \& Pacca, S. (2013). Energia eólica, geração de empregos e desenvolvimento sustentável. Estudos Avançados, 27(77). https://doi.org/10.1590/S0103-40142013000100008

WEG. (2017). Catálogo de Produtos. Retrieved from http://ecatalog.weg.net/files/wegnet/1-328.pdf

\section{Copyrights}

Copyright for this article is retained by the author(s), with first publication rights granted to the journal.

This is an open-access article distributed under the terms and conditions of the Creative Commons Attribution license (http://creativecommons.org/licenses/by/4.0/). 